\title{
Integrative network-based approaches for modeling human disease
}

Citation for published version (APA):

Ali, M. (2019). Integrative network-based approaches for modeling human disease. [Doctoral Thesis, Maastricht University]. Maastricht University. https://doi.org/10.26481/dis.20190830ma

Document status and date:

Published: 01/01/2019

DOI:

10.26481/dis.20190830ma

Document Version:

Publisher's PDF, also known as Version of record

\section{Please check the document version of this publication:}

- A submitted manuscript is the version of the article upon submission and before peer-review. There can be important differences between the submitted version and the official published version of record.

People interested in the research are advised to contact the author for the final version of the publication, or visit the DOI to the publisher's website.

- The final author version and the galley proof are versions of the publication after peer review.

- The final published version features the final layout of the paper including the volume, issue and page numbers.

Link to publication

\footnotetext{
General rights rights.

- You may freely distribute the URL identifying the publication in the public portal. please follow below link for the End User Agreement:

www.umlib.nl/taverne-license

Take down policy

If you believe that this document breaches copyright please contact us at:

repository@maastrichtuniversity.nl

providing details and we will investigate your claim.
}

Copyright and moral rights for the publications made accessible in the public portal are retained by the authors and/or other copyright owners and it is a condition of accessing publications that users recognise and abide by the legal requirements associated with these

- Users may download and print one copy of any publication from the public portal for the purpose of private study or research.

- You may not further distribute the material or use it for any profit-making activity or commercial gain

If the publication is distributed under the terms of Article $25 \mathrm{fa}$ of the Dutch Copyright Act, indicated by the "Taverne" license above, 


\section{Chapter 9}

\section{Summary}

The remarkable development of high-throughput sequencing technologies has allowed the generation of great quantities of genomic, epigenomic and transcriptomic data for various human diseases that has allowed us to dissect the mechanisms behind the onset and progression of multifactorial diseases. Owing to the multifactorial nature of most human disorders, recent advancements in computational disease modeling, by integrating regulatory information from different levels, provide a new framework for understanding the complex nature of human health and disease. For example, modelling of complex gene interaction networks has been very useful for disease modelling $[143,13,182]$ and for disentangling the interplay between different regulatory layers [193, 93, 195]. However, integrative network modelling approaches -i.e. linking different regulatory layers- $[193,93,195,104]$ are still scarce, which hampers the possibility of studying the crosstalk established among regulatory layers for determining a given phenotype or mediating phenotypic transitions [73]. As such, developing tailor-made computational models is a crucial step in understanding the contributions of genomic, epigenomic, and transcriptomic landscapes in cellular circuitry, lineage specification, and the onset and progression of human disease.

In order to bridge the gaps in the literature, we report integrative systems-level approaches to dissect the underlying disease mechanisms, helping in their early diagnosis as well as in designing potential therapeutic treatments. The research conducted in this thesis can be divided into five parts. CHAPTER 2 constitutes a concise overview of existing computational methods in the field of systems biology. Particular attention is paid to state-of-the-art gene regulatory network (GRN) 
based methods for instructive factors (IFs) determination and human disease modeling. Along with the strengths, the limitations of these methods are highlighted, thereby providing avenues for the research conducted and described in the following chapters.

Due to a clear lack of integrative methods for predicting more efficient sets of instructive factors, CHAPTER 3 describes INTREGNET, an integrative computational method for systematically identifying reliable minimal sets of IFs that can induce desired cellular conversions with increased efficiency. The application of this method is demonstrated in an in vitro setting, where limited conversion efficiency is a crucial barrier for its application in regenerative medicine.

As explained above, the heterogeneous and multifactorial nature of human disorders, such as Alzheimer's disease (AD), requires the integration of regulatory information from different -omics levels in order to capture the underlying mechanisms behind the onset and progression of this disease. In CHAPTER 4, global multi-omics alterations in AD patients are identified by comparing genomic (gene aberration), epigenomic (DNA methylation) and transcriptomic data sets of 46 diseased patients with 32 age-matched controls.

CHAPTER 5 features an integrative exploration of specific neurobiological pathways known to be impaired in AD. A comprehensive analysis of gene expression and DNA methylation levels is performed for genes known to be associated with sphingolipid function. The identified key genes and their particular methylation signatures offer mechanistic insights into AD pathology and may act as potential biomarkers.

In vitro modeling of human diseases allows us to gain crucial insights into mechanisms underlying disorders, hence devising and optimizing new strategies for therapeutic intervention. CHAPTER 6 features the differential network-based analysis of transcriptomic data sets obtained from brain organoids that served as an in vitro model of Batten disease. This study focuses on identifying key genes and pathways that are disrupted during the course of this disease.

In conclusion, we believe that the work conducted in this thesis provides the scientific community with a valuable resource to understand the underlying mechanism of multifactorial diseases from an integrative point of view, helping in their early diagnosis as well as in designing potential therapeutic treatments. 